\title{
SARS-CoV-2 nucleocapsid antigen in urine of hospitalized patients with Covid-19
}

\author{
Veyrenche $\mathrm{N}^{1}$, Pisoni $\mathrm{A}^{1}$, Debiesse $\mathrm{S}^{2}$, Bollore $\mathrm{K}^{2}$, Bedin $\mathrm{AS}^{2}$, Makinson $\mathrm{A}^{3}$, Niel $\mathrm{C}^{4}$, Alcocer-
} Cordellat $C^{4}$, Mondain $\mathrm{AM}^{4}$, Le Moing $\mathrm{V}^{3}$, Van de Perre $\mathrm{P}^{1}$, Tuaillon $\mathrm{E}^{1 \text { [ }}$

1. Pathogenesis and Control of Chronic and Emerging Infections, University of Montpellier, INSERM, EFS, University of Antilles; CHU Montpellier, Montpellier, France

2. Pathogenesis and Control of Chronic and Emerging Infections, University of Montpellier, INSERM, EFS, University of Antilles, Montpellier, France

3. Tropical and Infectious Diseases, University Hospital, Montpellier, France. INSERM U1175/IRD UMI 233, IRD, Montpellier, France

4. Montpellier University Hospital, Montpellier, France

Correspondence: e-tuaillon@chu-montpellier.fr 
medRxiv preprint doi: https://doi.org/10.1101/2021.09.28.21264239; this version posted October 1, 2021. The copyright holder for this preprint (which was not certified by peer review) is the author/funder, who has granted medRxiv a license to display the preprint in perpetuity.

All rights reserved. No reuse allowed without permission.

\section{ABSTRACT}

Introduction: SARS-CoV-2 nucleocapsid antigen ( $\mathrm{N}-\mathrm{Ag}$ ) can be detected in the blood of patients with Covid-19. In this study, we used a highly sensitive and specific nucleocapsid-Ag assay to explore the presence of $\mathrm{N}-\mathrm{Ag}$ in urine during the course of Covid-19, and explore its relationship with the severity of the disease.

Material and Methods: Urine and blood samples were collected from 82 patients with a SARS-CoV-2 infection proven by PCR and included in the COVIDotheque. We explored the presence of $\mathrm{N}-\mathrm{Ag}$ in urine and blood using the $\mathrm{AAZ} \mathrm{N}-\mathrm{Ag}$ test, studied the kinetics of the marker according to the time since the onset of symptoms and evaluated the association between $\mathrm{N}-\mathrm{Ag}$ levels, clinical severity and inflammation.

Results: In the first and second weeks of Covid-19, hospitalized patients tested positive for urinary $\mathrm{N}-\mathrm{Ag}$ (81.25\% and $71.79 \%$, respectively) and blood $\mathrm{N}-\mathrm{Ag}(93.75 \%$ and $94.87 \%$, respectively). $\mathrm{N}-\mathrm{Ag}$ levels in urine and blood were moderately correlated with the number of days after the onset of symptoms $(r=-0.43, p<0.0001 ; r=-0.55 p<0.0001$, respectively). The follow up of seven SARS-CoV-2 infected patients confirmed the waning of $\mathrm{N}-\mathrm{Ag}$ in urine and blood over the course of the disease. High urinary N-Ag levels were associated with the absence of SARS-CoV-2 nucleocapsid-IgG (N-IgG), admission in intensive care units, high Creactive protein levels, lymphopenia, eosinopenia, and high lactate dehydrogenase (LDH).

Conclusion: Our study demonstrate that N-Ag is present in the urine of patients hospitalized in the early phase of Covid-19. As a direct marker of SARS-CoV-2, urinary N-Ag reflects the dissemination of viral compounds in the body. Urine $\mathrm{N}-\mathrm{Ag}$ is a promising marker to predict adverse evolution of SARS-CoV-2 infections. 
medRxiv preprint doi: https://doi.org/10.1101/2021.09.28.21264239; this version posted October 1, 2021. The copyright holder for this preprint (which was not certified by peer review) is the author/funder, who has granted medRxiv a license to display the preprint in perpetuity.

All rights reserved. No reuse allowed without permission.

\section{INTRODUCTION}

The SARS-CoV-2 pandemic has upset the world and challenged medical knowledge about viral respiratory infections. One of the major characteristics of SARS-CoV-2 infection is the diversity of clinical expression, with a wide range of symptoms reported in infected persons

1. While severe forms constitute only a small share of Covid-19 cases, they put major pressure on health systems and are responsible for the direct excess mortality associated with the pandemic.

Although knowledge on the natural history of Covid-19 has improved considerably over the last 18 months, the exact mechanisms of impairment in the innate and adaptive immune system leading to severe forms of Covid-19 remain to be elucidated. According to our current understanding of the pathophysiology, different phases of virus and host interactions characterize SARS-CoV-2 infection ${ }^{2}{ }^{3}$. Following the incubation period, a high viral replication triggers the innate immune response. A strong inflammatory syndrome and the onset of the adaptive immune response characterize the second phase of Covid-19 before recovery or worsening. Severe forms of Covid-19 are associated with an excessive release of cytokines, known as a "cytokine storm", occurring generally during the second phase of the disease ${ }^{4}$. The administration of corticosteroids reduces death and time to recovery ${ }^{5}$, and numerous interventional trials aim to limit this excessive inflammation using various immunomodulating treatments ${ }^{6}$.

On the virus side of the host-virus interplay, the contribution to disease severity of a high SARS-CoV-2 load measured in respiratory samples remains uncertain. SARS-CoV-2 RNA detection in nasopharyngeal swabs remains the gold standard for the diagnosis of infection. The kinetics of SARS-CoV-2 RNA in the upper respiratory tract during the course of Covid-19 is well established, with high concentrations observed during the initial phase, followed by a rapid decrease in the second week after the onset of symptoms, and a low or undetectable level of RNA later ${ }^{7}$. The viral loads of asymptomatic or mild forms of SARS-CoV-2 infections are similar to severe forms ${ }^{8}$. Recent studies suggest that SARS-CoV-2 RNA decreases faster in mild/asymptomatic infections and in young subjects compared to severe forms and elderly subjects ${ }^{9}{ }^{10}$. The presence of SARS-CoV-2 components also has been reported outside the respiratory tract, such as in blood, stool and saliva. When detected, the plasma SARS-CoV-2 RNA level is generally low, and to date the virus has not been isolated from 
peripheral blood. Furthermore, no case of SARS-CoV-2 transmission via transfusion has been described ${ }^{11}$. On the other hand, the presence of the SARS-CoV-2 nucleocapsid has been reported in the blood of Covid-19 patients. Data from two studies suggest that this circulating antigen $(\mathrm{Ag})$ is detectable in almost all hospitalized patients in the early phase of the disease ${ }^{12}$. A high level of nucleocapsid antigenemia $(\mathrm{N}-\mathrm{Ag})$ could be associated with severe forms of Covid-19 and the presence of circulating SARS-CoV-2 RNA ${ }^{13}$. To date, the detection of antigens has only been evaluated in respiratory fluids, blood and saliva.

In this study, we used a highly sensitive and specific nucleocapsid-Ag assay to: i) explore the presence of $\mathrm{N}-\mathrm{Ag}$ in the urine of hospitalized patients, ii) study the kinetics of $\mathrm{N}-\mathrm{Ag}$ concentration in urine and blood during infection, iii) assess the relationship between $\mathrm{N}-\mathrm{Ag}$ concentrations in urine and blood, and iv) compare urine and blood N-Ag levels in moderate versus severe forms of Covid-19. 
medRxiv preprint doi: https://doi.org/10.1101/2021.09.28.21264239; this version posted October 1, 2021. The copyright holder for this preprint (which was not certified by peer review) is the author/funder, who has granted medRxiv a license to display the preprint in perpetuity.

All rights reserved. No reuse allowed without permission.

\section{MATERIALS AND METHODS}

Samples and ethics. Plasma, urine and nasopharyngeal samples were collected from 82 SARS-CoV-2 infected patients admitted in Montpellier University hospitals between March 2020 and May 2021 and consenting to be included in a cohort of patients with confirmed SARS-CoV-2 (COVIDotheque cohort). A total of 82 plasma and 82 urine paired samples were taken the same day or within a maximum of 48 hours apart. In addition, series of urine and blood paired samples were collected in seven patients for a follow-up (28 paired samples). The estimated date of the onset of symptoms was recorded and ranged from 1 to 35 days before hospital admission. The SARS-CoV-2 infected patients were allocated in two groups: those hospitalized in an intensive care unit (ICU) and those not in ICU. Patient characteristics are detailed in Table 1. Controls consisted of consenting patients who were not suspected of Covid-19 and tested negative for SARS-CoV-2 RNA in nasopharyngeal samples. All tests were performed in the Virology laboratory of the CHU Montpellier. The cohort study received an institutional ethics committee approval (CPP Ile de France III, n²020-A00935-34; ClinicalTrials. gov Identifier: $\underline{\text { NCT04347850)}}$.

Reverse transcription polymerase chain reaction (RT-PCR) method. RT-PCR on nasopharyngeal samples was performed by Seegene STARlet IVD for automated nucleic acids extraction and PCR setup. The Allplex 2019-nCoV Assay (Seegene) kit was used to confirm SARS-CoV-2 infection. This RT-PCR targeted SARS-CoV-2 RNA-dependent RNA polymerase $(R d R P)$, the SARS-CoV-2 nucleocapsid (N) and the sarbecovirus envelope (E) gene. Nasopharyngeal samples were tested within a few hours after collection and without any cooling or freezing step. Various transport media were used to collect nasopharyngeal with swabs: eSwab COPAN Amies 1?ml, $\sum$-Transwab liquid Amies, viral transport medium tube VTM-M 2.0?ml. For each sample, the lower gene cycle threshold (Ct) was recorded.

SARS-CoV-2 N IgG and IgA assay on plasma. SARS-CoV- N IgG and IgA detection was performed on plasma samples by indirect semi-quantitative ELISA ID Screen ${ }^{\circledR}$ ID.Vet. This assay detects IgG and IgA antibodies directed against the nucleocapsid of SARS-CoV-2 in plasma samples. The manufacturer's instructions defined the cut-off value for a positive 
medRxiv preprint doi: https://doi.org/10.1101/2021.09.28.21264239; this version posted October 1, 2021. The copyright holder for this preprint (which was not certified by peer review) is the author/funder, who has granted medRxiv a license to display the preprint in perpetuity.

All rights reserved. No reuse allowed without permission.

result: a signal ratio "Sample/Positive control\%" (S/P\%) $\geq 40 \%$ was considered positive, $30 \%<\mathrm{S} / \mathrm{P} \%<40 \%$ was considered suspicious and S/P\% $\leq 30$ was considered negative.

SARS-CoV-2 N IgG and IgA assay on urine. SARS-CoV- N IgG and IgA detection was performed on urine samples by indirect semi-quantitative ELISA ID Screen ${ }^{\circledR}$ ID.Vet. This assay detects IgG and IgA antibodies directed against the nucleocapsid of SARS-CoV-2 in plasma samples. A signal ratio "Sample/Positive control\%" (S/P\%) $\geq 40 \%$ was considered positive, $30 \%<\mathrm{S} / \mathrm{P} \%<40 \%$ was considered suspicious and S/P\% $\leq 30$ was considered negative.

$\mathrm{N}$-antigen detection. N-SARS-CoV-2 antigen levels in urine and plasma were determined with a CE-IVD ELISA microplate assay, COVID-Quantigene ${ }^{\circledR}$ (AAZ-LMB, Boulogne-Billancourt, France). This assay detects $\mathrm{N}$ antigen by direct quantitative ELISA. The cut-off value was defined by the manufacturer's instructions: samples with antigen $\mathrm{N}$ concentration $\geq 2.97$ $\mathrm{pg} / \mathrm{mL}$ were considered positive.

Software and statistical analyses. Mann-Whitney $U$ test was used to compare the differents quantitatives variables with non-normal distribution (Fig 1. $\mathrm{H}$ and I ; Fig 2. A and B ; Fig. 3 A and B ; Fig.4 A-P). Because the distribution was non-normal and total of the discordant pairs was too low, Exact binomial's test was used to compare the proportion of patients with urine N-Ag and/or plasma N-Ag (Fig 1.A and B). Correlations were calculated by Spearman's coefficient (Fig $1 \mathrm{C}-\mathrm{E}, \mathrm{J}$ and $\mathrm{K}$ ). The median and interquartile range (IQR) were used to describe cohort characteristics. Data were analyzed using Excel 2016 (Microsoft Corp, Redmond, Washington) and GraphPad Prism 9.1.1.0 (Microsoft Corp, Redmond, Washington).

\section{RESULTS}

\section{$\mathrm{N}-\mathrm{Ag}$ is present in the urine of patients hospitalized with SARS-CoV-2 infection}

We tested the presence of $\mathrm{N}-\mathrm{Ag}$ in urine samples of 82 patients hospitalized for a SARS-CoV2 infection confirmed by RT-PCR. N-Ag was present in the urine of $41 / 55$ patients $(74.55 \%)$ tested during the first two weeks after the onset of symptoms, (Se: $81.25 \%$ and $71.79 \%$, respectively) with concentrations ranging from 1.00 to $9613.03 \mathrm{pg} / \mathrm{mLFig}$. 1.A). All urine samples from control subjects tested negative for $\mathrm{N}-\mathrm{Ag}$ (Sp: 100\%; data not shown). In 
medRxiv preprint doi: https://doi.org/10.1101/2021.09.28.21264239; this version posted October 1, 2021. The copyright holder for this preprint (which was not certified by peer review) is the author/funder, who has granted medRxiv a license to display the preprint in perpetuity.

All rights reserved. No reuse allowed without permission.

blood-paired samples, N-Ag was detected from 53/55 (94.64\%) patients tested during the first two weeks after the onset of symptoms (Se: $93.75 \%$ and $94.87 \%$, respectively) with concentrations ranging from 1.00 to $16019.30 \mathrm{pg} / \mathrm{mL}$ (Fig. 1.B). Urine N-Ag levels correlated with blood concentrations ( $r=0.7354$ ) (Fig. 1.E).

\section{Urinary $\mathrm{N}-\mathrm{Ag}$ concentrations decrease over time but remain detectable during the second week after the onset of symptoms and after nucleocapsid IgG (N-IgG) seroconversion}

$\mathrm{N}-\mathrm{Ag}$ levels in urine was inversely correlated with the number of days after the onset of symptoms (fig. 1.C) $(r=-0.43 ; p<0.0001)$. Urinary $\mathrm{N}-\mathrm{Ag}$ levels were high in samples collected during the first and second week after the onset of symptoms and decreased sharply during the third week (Supplemental Figure S1.A). Blood N-Ag correlated well with the number of days after the onset of symptoms $(r=-0.55 ; p<0.0001)$, and also decreased after the first two weeks (Supplemental Figure S1.B). The follow-up of seven SARS-CoV-2 infected patients confirmed the gradual decrease of urine and blood N-Ag levels over time (Fig 1.F, G).

The analysis of blood $\mathrm{N}-\mathrm{Ag}$ according to serological status against SARS-CoV-2 nucleocapsid showed lower concentrations in $\mathrm{N}$-lgG positive patients compared to $\mathrm{N}$-lgG negative patients. However, most patients (81.36\%) who tested positive for SARS-CoV-2 nucleocapsid IgG remained positive for blood $\mathrm{N}-\mathrm{Ag}$ (Fig 1.I). The level of $\mathrm{N}-\mathrm{Ag}$ in the urine was also significantly lower in patients who tested positive for circulating anti-N IgG compared to $\mathrm{N}$ IgG negative patients, but we observed a less pronounced difference between the two groups than in blood (Fig 1.H-J. CT results of SARS-CoV-2 RNA PCR in nasopharyngeal swabs were not correlated with urine $\mathrm{N}-\mathrm{Ag}$ level ( $\mathrm{r}=-0.23, \mathrm{p}=0.1077$; Fig 1.K), and weakly correlated with blood N-Ag ( $r=-0.34, p=0.0162$; Fig 1.K).

Urine samples also were assessed for antibodies against SARS-CoV-2 nucleocapsid (Figure 2). Patients tested negative for nucleocapsid antibodies in plasma tested also negative for both $\mathrm{N}-\lg \mathrm{A}$ and $\mathrm{N}-\lg G$ in urine. Signal ratios for $\mathrm{N}-\operatorname{lgA}$ and $\mathrm{N}-\lg G$ were higher in urine samples collected after seroconversion has occurred $(p<0.0001)$. Using the same threshold as for plasma, $\mathrm{N}$-IgA were detected in $17 / 82$ patients (20.7\%), and $\mathrm{N}-\lg$ in $6 / 82$ (7.3\%) patients. All urine samples from SARS-CoV-2 negative controls tested negative for $\mathrm{N}-\mathrm{IgG}$ and $\mathrm{N}$-IgA (data not shown). 
medRxiv preprint doi: https://doi.org/10.1101/2021.09.28.21264239; this version posted October 1, 2021. The copyright holder for this preprint (which was not certified by peer review) is the author/funder, who has granted medRxiv a license to display the preprint in perpetuity.

All rights reserved. No reuse allowed without permission.

\section{High urinary $\mathrm{N}-\mathrm{Ag}$ levels are associated with admission in intensive care units}

Patients had higher urinary N-Ag levels when hospitalized in intensive care units (ICU) compared to medical wards ( $p=0.0077$ ) (Fig. 3.A). The levels were higher in ICU seronegative hospitalized patients ( $\mathrm{p}=0.0112)$, and a trend toward a higher level of $\mathrm{N}-\mathrm{Ag}$ was observed in ICU seropositive patients ( $\mathrm{p}=0.0559$ ) (Fig 3.A). Blood N-Ag levels were also higher in patients hospitalized in ICU compared to medical wards ( $p=0.0250)$ (Fig 3B). The ROC curves show that both high urine and blood $\mathrm{N}-\mathrm{Ag}$ levels were predictive of a condition requiring intensive care (Fig 3.C, 3.D). A higher accuracy was observed for urine N-Ag as a predictor of severe Covid-19 compared to blood N-Ag, especially on seronegative patients (AUC: 0.8300 vs 0.7115 , respectively).

\section{Relationship of urine and blood N-Ag levels with biological markers of Covid-19 severity}

Levels of urine and plasma $\mathrm{N}-\mathrm{Ag}$ were analyzed according to abnormalities in biological markers associated with Covid-19 severity (Fig 4.). Higher urine and blood N-Ag levels were measured among patients with a C-reactive protein (CRP) over $100 \mathrm{mg} / \mathrm{L}$. The differences remained significant when $\mathrm{N}-\mathrm{Ag}$ levels in urine and blood were analyzed according to $\mathrm{N}-\lg \mathrm{g}$ serological status. Higher urine and blood N-Ag levels also were measured among patients with lymphopenia and low eosinophil counts. Urine N-Ag levels were higher when the Lactate dehydrogenase (LDH) level was elevated. We did not observe an association between $\mathrm{N}-\mathrm{Ag}$ levels and low platelet counts $(<200 / \mu \mathrm{L})$, abnormal troponin levels (>60 mg/mL), high Ddimer levels (> $1200 \mathrm{mg} / \mathrm{mL}$ ), or the glomerular Filtration Rate (GFR) based on the Modification of Diet in Renal Disease (MDRD) study equation $(<60 \mathrm{ml} / \mathrm{min} / 1.73 \mathrm{~m} 2)$. Urine $\mathrm{N}-\mathrm{Ag}$ levels were lower in patients with elevated alanine aminotransferase (ALT) concentrations. 
medRxiv preprint doi: https://doi.org/10.1101/2021.09.28.21264239; this version posted October 1, 2021. The copyright holder for this preprint (which was not certified by peer review) is the author/funder, who has granted medRxiv a license to display the preprint in perpetuity.

All rights reserved. No reuse allowed without permission.

\section{DISCUSSION}

In this study, we assess $\mathrm{N}-\mathrm{Ag}$ in urine of patients hospitalized for a Covid-19 infection confirmed by PCR. We analysed N-Ag levels in urine according to time after symptoms onset, level of antigenemia, serological status and severity. Our results demonstrate that $\mathrm{N}-\mathrm{Ag}$ is present in urine of patients hospitalized for a SARS-CoV-2 infection. Urinary $\mathrm{N}-\mathrm{Ag}$ concentrations decreased progressively after the onset of symptoms following two phases: a low decay during the first and second weeks, and a sharp decrease during the third week. The presence of circulating antibodies against nucleocapsid was associated with a lower level of urine $\mathrm{N}-\mathrm{Ag}$, but the SARS-CoV-2 nucleocapsid remained detectable in the urine samples of most of the patients seropositive for $\mathrm{N}$-lgG.

It is thought that severe forms of the disease are caused by an inappropriate host response to SARS-CoV-2, with an inefficient innate response during the first week after the onset of symptoms, followed by an over inflammation corresponding to systemic cytokine storm thereafter. Steroid treatments reduce mortality related to Covid-19 in hospitalized patients requiring oxygen ${ }^{14}$. Studies using interleukin-6 antagonist Tocilizumab also have obtained encouraging results ${ }^{15} 16$. Levels of SARS-CoV-2 RNA in the upper respiratory track do not appear to be a reliable marker of Covid-19 severity since high concentrations of virus in nasopharyngeal and saliva specimens are observed in asymptomatic, mild and severe forms of SARS-CoV-2 infections ${ }^{17}$. Blood SARS-CoV-2 RNA is more frequently detectable and found at higher levels in severe forms of Covid-19 ${ }^{18}{ }^{19}$. SARS-CoV-2 viremia is associated with disease severity, patient outcome and inflammatory biomarkers ${ }^{20}$. Ciliated and AT2 cells in airway and alveolar regions are the first targets of SARS-CoV-2. However, systemic clinical manifestations suggest that SARS-CoV-2 also can infect different organs through the bloodstream, such as endothelial cells ${ }^{21}$, gastrointestinal cells and ACE2 positive distal tubule cells ${ }^{22}$. Furthermore, the administration of convalescent plasma therapy ${ }^{23}$ and monoclonal antibodies (mAb) against the Spike protein help improve Covid-19 recovery ${ }^{24}$. All together, these observations suggest that SARS-CoV-2 replication and plasma viremia may contribute severity of Covid-19.

The first reports on Covid-19 infrequently detected circulating SARS-CoV-2 RNA ${ }^{25}$. Recent studies have inconsistently detected SARS-CoV-2 RNA, and generally with a low viral load 26,27 . In contrast, in the study of Le Hingrat et al. using the same assay as in our study, N- 
medRxiv preprint doi: https://doi.org/10.1101/2021.09.28.21264239; this version posted October 1, 2021. The copyright holder for this preprint (which was not certified by peer review) is the author/funder, who has granted medRxiv a license to display the preprint in perpetuity.

All rights reserved. No reuse allowed without permission.

antigenemia appeared to be a sensitive marker of SARS-CoV-2 infection in hospitalized patients, able to provide a surrogate test to molecular approaches ${ }^{12}$. Dandan S. et al. confirmed this observation using a digital enzyme-linked immunosorbent method ${ }^{13}$. In line with these studies, we observed that the N-Ag levels in our population of hospitalized patients most of the time were over $100 \mathrm{pg} / \mathrm{mL}$ during the first week after the onset of symptoms, and remained largely over the lower limit of quantification of the assay during the second week. Given the much better analytical sensitivity of PCR methods compared to antigen immunoassays, these findings are surprising. SARS-CoV-2 nucleocapsid antigen may be released in the bloodstream or circulate after destruction of the virus particle and virus RNA. Additionally, SARS-CoV-2 nucleocapsid antigen produced in excess during profuse viral replication and non-included in virions.

Detection of SARS-CoV-2 RNA in urine specimens has been reported in less than $5 \%$ of confirmed Covid-19 cases ${ }^{28}$. Using mass spectrometry, Mishra $\mathrm{C}$ et al. have reported detection of nucleocapsid-derived peptides in urine of a third of Covid-19 patients ${ }^{29}$. Our results using a highly sensitive immunoassay demonstrate the presence of $\mathrm{N}$-antigen in urine in most of Covid-19 hospitalized patients during the first two weeks after onset of the symptoms.

The kidney is among the most frequently affected extrapulmonary organs during SARS-CoV-2 infection, and varying degrees of renal damage have been reported in COVID-19 patients ${ }^{30}$ ${ }^{31}$. Acute kidney disease was observed in a quarter of the patients included in our study. We observed high concentrations of urine $\mathrm{N}-\mathrm{Ag}$ during the first two weeks after the onset of symptoms, and no association between urine $\mathrm{N}-\mathrm{Ag}$ levels and altered renal function. The origin of $\mathrm{N}$-antigen detected in urine is uncertain. $\mathrm{N}-\mathrm{Ag}$ in urine may originate from the blood and be excreted by the kidney, as suggested by the correlation between N-Ag concentrations in blood and urine. The SARS-CoV-2 nucleocapsid is a $46 \mathrm{kd}$ protein. The glomerular permeability and filtration probably permit the excretion of this small-size protein. However, the C-terminal region of the SARS-CoV-2 nucleocapsid possesses binding affinity to form dimers that produce large compounds that may be not be filtered by the kidney. Furthermore, after seroconversion against the nucleocapsid, immune complexes also form, with a size that makes them unable to be filtered. Of note, although Covid-19 associated glomerular disease has been reported, this type of kidney injury seems infrequent among 
medRxiv preprint doi: https://doi.org/10.1101/2021.09.28.21264239; this version posted October 1, 2021. The copyright holder for this preprint (which was not certified by peer review) is the author/funder, who has granted medRxiv a license to display the preprint in perpetuity.

All rights reserved. No reuse allowed without permission.

acute kidney diseases associated to SARS-CoV-2 infection ${ }^{32}$. A local production of SARS-CoV2 nucleocapsid may be another possible origin of the antigen detected in urine. Alongside hypoxia, circulating disorder and inflammation, SARS-CoV-2 infection may directly contribute to kidney injury. Cells expressing ACE2 are present in the tubules, and studies have shown that SARS-CoV-2 RNA, nucleocapsid and spike protein accumulate in tubules ${ }^{33} 22$.

Both blood and urine $\mathrm{N}-\mathrm{Ag}$ levels may reflect SARS-CoV-2 disseminated infection. We observed a moderate correlation between $\mathrm{N}-\mathrm{Ag}$ in blood and urine, but the kinetic of this marker may be different in these two compartments. The development of anti-nucleocapsid humoral response may induce the formation of immune complexes that interfere with $\mathrm{N}-\mathrm{Ag}$ quantification in blood. Hence, after seroconversion N-Ag and N-IgG levels may represent only the unbound fraction available to be measured by the immunoassays. In urine, antibodies directed against nucleocapsid were only detected in one quarter of the patients who tested positive for circulating $\mathrm{N}-\mathrm{IgG}$, limiting the risk of underestimation of $\mathrm{N}-\mathrm{Ag}$ levels by the immunoassay. In other words, $\mathrm{N}-\mathrm{Ag}$ levels in urine may be more accurate since nucleocapsid $\mathrm{Ag}$ quantitation in urine is probably less impacted by the formation of immune Ag-Abs complexes compared to blood. $\mathrm{N}-\mathrm{Ag}$ in urine may better reflect disseminated infection than nucleocapsid antigenemia, especially after seroconversion against SARS-CoV-2 nucleoprotein. Besides interfering with assay measurement, the presence of circulating antibody-antigen complexes may bind FC receptors activating monocytes/macrophages, and fuel the hyperinflammation observed in the second phase of Covid-19 ${ }^{34}$.

Risk factors related to age and comorbidities, alongside inflammation and cytopenia, are associated with the development of severe forms of Covid-19 requiring hospitalisation and intensive care. At present, however, the progression to a severe form of Covid-19 remains unpredictable. We observed higher concentrations of urine $\mathrm{N}-\mathrm{Ag}$ in samples collected in patients hospitalised in intensive care units compared to medical wards. This result is in line with the study of Caceres P. et al., reporting that SARS-CoV-2 viral load in urine sediments was associated with higher mortality in hospitalized patients ${ }^{17}$. Furthermore, in our study, urine and plasma N-Ag levels were associated with several early markers of Covid-19 severity, such as lymphopenia, low eosinophil count, and CRP levels. We observed lower levels of urine $\mathrm{N}-\mathrm{Ag}$ in patients with abnormal ALT, which may be because liver injury is 
medRxiv preprint doi: https://doi.org/10.1101/2021.09.28.21264239; this version posted October 1, 2021. The copyright holder for this preprint (which was not certified by peer review) is the author/funder, who has granted medRxiv a license to display the preprint in perpetuity.

All rights reserved. No reuse allowed without permission.

delayed after the first week in the course of prolonged Covid-19 while the decay of $\mathrm{N}-\mathrm{Ag}$ is already underway ${ }^{35}$.

Our study has several limitations. The population is not representative of SARS-CoV-2 infected individuals. All of the subjects had mild or severe forms of Covid-19 and required oxygen, whereas a majority of SARS-CoV-2 infected individuals do not require hospitalization. In addition, patients requiring critical care are over-represented because their urine samples frequently were collected in routine care. We did not assess the value of $\mathrm{N}-\mathrm{Ag}$ as a predictive marker of adverse evolution but only as a marker associated to severe Covid-19. Finally, N-Ag levels were analysed on a single urine sample while results on urine samples collected taken over a 24-hour period would be more accurate.

In conclusion, these results demonstrate that $\mathrm{N}-\mathrm{Ag}$ is present in urine of patients hospitalized for Covid-19. As a direct marker of SARS-CoV-2 infection, urinary and blood N$\mathrm{Ag}$ reflect the dissemination of viral compounds in the body and probably SARS-CoV-2 replication. Further studies are required to evaluate the value of urinary $\mathrm{N}-\mathrm{Ag}$ to predict the adverse evolution of SARS-CoV-2 infections.

\section{ACKNOWLEDGMENTS}

The author would like to thank Grace Delobel for English language editing and review services. This work was funded by the Montpellier University Hospital, Muse I-SITE Program Grant, University of Montpellier.

\section{AUTHOR CONTRIBUTIONS}

N. V. has performed experiments, statistical analysis, and wrote the manuscript. A. P., C. N. and C. A. C. have performed experiments. A. P. has helped to use GraphPad Prism 9.1.1.0. S. D., K. B., A.-S. B., A.M. M., A. M., V. L. M. and P. V. P. have discussed the results and critically reviewed the manuscript. E. T. has conceived the study, discussed the results and wrote the manuscript. All authors contributed to the article and approved the submitted version.

\section{COMPETING INTERESTS}


medRxiv preprint doi: https://doi.org/10.1101/2021.09.28.21264239; this version posted October 1, 2021. The copyright holder for this preprint (which was not certified by peer review) is the author/funder, who has granted medRxiv a license to display the preprint in perpetuity. All rights reserved. No reuse allowed without permission.

The authors declare that there are no conflict of interests or personal relationships that could have appeared to influence the work reported in this paper.

\section{DATA AVAILABILITY STATEMENT}

The data that support the findings of this study are available from the corresponding author upon reasonable request. 
medRxiv preprint doi: https://doi.org/10.1101/2021.09.28.21264239; this version posted October 1, 2021. The copyright holder for this preprint (which was not certified by peer review) is the author/funder, who has granted medRxiv a license to display the preprint in perpetuity.

All rights reserved. No reuse allowed without permission.

\section{REFERENCES}

1. Chen, G. et al. Clinical and immunological features of severe and moderate coronavirus disease 2019. Journal of Clinical Investigation 130, 2620-2629 (2020).

2. Blanco-Melo, D. et al. Imbalanced Host Response to SARS-CoV-2 Drives Development of COVID-19. Cell 181, 1036-1045.e9 (2020).

3. Patel, S., Saxena, B. \& Mehta, P. Recent updates in the clinical trials of therapeutic monoclonal antibodies targeting cytokine storm for the management of COVID-19. Heliyon 7, e06158 (2021).

4. Fajgenbaum, D. C. \& June, C. H. Cytokine Storm. N Engl J Med 383, 2255-2273 (2020).

5. The RECOVERY Collaborative Group. Dexamethasone in Hospitalized Patients with Covid19. N Engl J Med 384, 693-704 (2021).

6. Mølhave, M., J, A. \& C, W. Clinical Management of COVID-19 Patients - An Update. Seminars in Nuclear Medicine S0001299821000362 (2021) doi:10.1053/j.semnuclmed.2021.06.004.

7. Wölfel, R. et al. Virological assessment of hospitalized patients with COVID-2019. Nature 581, 465-469 (2020).

8. Long, Q.-X. et al. Clinical and immunological assessment of asymptomatic SARS-CoV-2 infections. Nat Med 26, 1200-1204 (2020).

9. He, X. et al. Temporal dynamics in viral shedding and transmissibility of COVID-19. Nat Med 26, 672-675 (2020).

10. Néant, N. et al. Modeling SARS-CoV-2 viral kinetics and association with mortality in hospitalized patients from the French COVID cohort. Proc Natl Acad Sci USA 118, e2017962118 (2021). 
medRxiv preprint doi: https://doi.org/10.1101/2021.09.28.21264239; this version posted October 1, 2021. The copyright holder for this preprint (which was not certified by peer review) is the author/funder, who has granted medRxiv a license to display the preprint in perpetuity.

All rights reserved. No reuse allowed without permission.

11. Cappy, P. et al. No evidence of SARS-CoV-2 transfusion transmission despite RNA detection in blood donors showing symptoms after donation. Blood 136, 1888-1891 (2020).

12. Le Hingrat, Q. et al. Detection of SARS-CoV-2 N-antigen in blood during acute COVID-19 provides a sensitive new marker and new testing alternatives. Clinical Microbiology and Infection 27, 789.e1-789.e5 (2021).

13. Shan, D. et al. N-protein presents early in blood, dried blood and saliva during asymptomatic and symptomatic SARS-CoV-2 infection. Nat Commun 12, 1931 (2021).

14. WHO/2019-nCoV/Corticosteroids/2020.1.

15. Salama, C. et al. Tocilizumab in Patients Hospitalized with Covid-19 Pneumonia. N Engl J Med 384, 20-30 (2021).

16. Rosas, I. O. et al. Tocilizumab in Hospitalized Patients with Severe Covid-19 Pneumonia. N Engl J Med 384, 1503-1516 (2021).

17. Hasanoglu, I. et al. Higher viral loads in asymptomatic COVID-19 patients might be the invisible part of the iceberg. Infection 49, 117-126 (2021).

18. The Massachusetts Consortium for Pathogen Readiness et al. SARS-CoV-2 viral load is associated with increased disease severity and mortality. Nat Commun 11, 5493 (2020).

19. Xu, D. et al. Relationship Between Serum Severe Acute Respiratory Syndrome Coronavirus 2 Nucleic Acid and Organ Damage in Coronavirus 2019 Patients: A Cohort Study. Clinical Infectious Diseases 73, 68-75 (2021).

20. Järhult, J. D., Hultström, M., Bergqvist, A., Frithiof, R. \& Lipcsey, M. The impact of viremia on organ failure, biomarkers and mortality in a Swedish cohort of critically ill COVID-19 patients. Sci Rep 11, 7163 (2021). 
medRxiv preprint doi: https://doi.org/10.1101/2021.09.28.21264239; this version posted October 1, 2021. The copyright holder for this preprint (which was not certified by peer review) is the author/funder, who has granted medRxiv a license to display the preprint in perpetuity.

All rights reserved. No reuse allowed without permission.

21. Varga, Z. et al. Endothelial cell infection and endotheliitis in COVID-19. The Lancet 395, $1417-1418$ (2020).

22. Diao, B. et al. Human kidney is a target for novel severe acute respiratory syndrome coronavirus 2 infection. Nat Commun 12, 2506 (2021).

23. Senefeld, J. W. et al. Use of convalescent plasma in COVID-19 patients with immunosuppression. Transfusion 61, 2503-2511 (2021).

24. Weinreich, D. M. et al. REGN-COV2, a Neutralizing Antibody Cocktail, in Outpatients with Covid-19. N Engl J Med 384, 238-251 (2021).

25. Wang, W. et al. Detection of SARS-CoV-2 in Different Types of Clinical Specimens. JAMA (2020) doi:10.1001/jama.2020.3786.

26. Regan, J. et al. Viral Load Kinetics of Severe Acute Respiratory Syndrome Coronavirus 2 in Hospitalized Individuals With Coronavirus Disease 2019. Open Forum Infectious Diseases 8, ofab153 (2021).

27. Jacobs, J. L. et al. SARS-CoV-2 Viremia is Associated with COVID-19 Severity and Predicts Clinical Outcomes. Clinical Infectious Diseases ciab686 (2021) doi:10.1093/cid/ciab686.

28. Mishra, C., Meena, S., Meena, J. K., Tiwari, S. \& Mathur, P. Detection of three pandemic causing coronaviruses from non-respiratory samples: systematic review and metaanalysis. Sci Rep 11, 16131 (2021).

29. Chavan, S. et al. Mass Spectrometric Analysis of Urine from COVID-19 Patients for Detection of SARS-CoV-2 Viral Antigen and to Study Host Response. J. Proteome Res. 20, 3404-3413 (2021).

30. Puelles, V. G. et al. Multiorgan and Renal Tropism of SARS-CoV-2. N Engl J Med 383, 590$592(2020)$ 
medRxiv preprint doi: https://doi.org/10.1101/2021.09.28.21264239; this version posted October 1, 2021. The copyright holder for this preprint (which was not certified by peer review) is the author/funder, who has granted medRxiv a license to display the preprint in perpetuity. All rights reserved. No reuse allowed without permission.

31. Legrand, M. et al. Pathophysiology of COVID-19-associated acute kidney injury. Nat Rev Nephrol (2021) doi:10.1038/s41581-021-00452-0.

32. Shetty, A. A. et al. COVID-19-Associated Glomerular Disease. JASN 32, 33-40 (2021).

33. Lin, H. et al. Identification of a special cell type as a determinant of the kidney tropism of SARS-CoV-2. FEBS J febs.16114 (2021) doi:10.1111/febs.16114.

34. Merad, M. \& Martin, J. C. Pathological inflammation in patients with COVID-19: a key role for monocytes and macrophages. Nat Rev Immunol 20, 355-362 (2020).

35. Ding, Z. et al. Association of liver abnormalities with in-hospital mortality in patients with COVID-19. Journal of Hepatology 74, 1295-1302 (2021). 
Table 1. Patient characteristics

\begin{tabular}{|c|c|c|c|c|c|}
\hline \multirow[b]{2}{*}{ Clinical and biological characteristics ${ }^{\dagger}$} & \multicolumn{3}{|c|}{ Confirmed COVID-19 } & \multicolumn{2}{|r|}{ Controls } \\
\hline & $\begin{array}{c}\text { Total } \\
(n=82)\end{array}$ & $\begin{array}{c}\text { Medical ward patients } \\
(n=24)\end{array}$ & $\begin{array}{c}\text { ICU patients } \\
(n=58)\end{array}$ & Pvalue & $(n=32)$ \\
\hline$M / F$ & $58 / 24$ & $15 / 9$ & $43 / 15$ & $0.29^{\mu}$ & $15 / 17$ \\
\hline Median age & $63.0(53.0-74.25)$ & $66.50(49.00-79.25)$ & $62.50(54.75-73.25)$ & $0.82^{\#}$ & $55.0(31.5-68.75)$ \\
\hline Age $\geq 65(\%)$ & $39(47.6)$ & $13(54.2)$ & $26(44.8)$ & $0.44^{\mu}$ & $13(40.6)$ \\
\hline Median time since onset of symptoms (days) & $12(9-16)$ & $11.5(7.5-17.0)$ & $12.0(9.0-16.0)$ & $0.75^{\#}$ & - \\
\hline SARS-CoV-2 RNA PCR cycle threshold (CT) & $27.8(22.6-32.8)$ & $29.5(21.1-36.3)$ & $26.9(22.7-31.5)$ & 0.54 & - \\
\hline SARS-CoV-2 nucleocapsid IgG positive (\%) & $48(58.5)$ & $13(54.2)$ & $35(60.3)$ & 0.61 & - \\
\hline Platelet count $\left(10^{3} / \mathrm{mm}^{3}\right)$ & $236.0(167.0-334.5)$ & $256.5(135.3-391.8)$ & $232.0(185.0-301.5)$ & $0.68^{\#}$ & - \\
\hline Lymphocyte count $\left(10^{3} / \mathrm{mm}^{3}\right)$ & $0.93(0.55 .0-1.29)$ & $1.11(0.93-1.41)$ & $0.82(0.49-1.16)$ & $0.01^{\#}$ & - \\
\hline Neutrophil count $\left(10^{3} / \mathrm{mm}^{3}\right)$ & $5.91(3.70-9.19)$ & $4.62(3.09-6.89)$ & $6.42(3.91-9.57)$ & $0.11^{\#}$ & - \\
\hline Eosinophil count $\left(10^{3} / \mathrm{mm}^{3}\right)$ & $0.06(0.03-0.11)$ & $0.06(0.03-0.11)$ & $0.06(0.03-0.12)$ & $0.67^{\#}$ & - \\
\hline C-reactive protein $(\mathrm{mg} / \mathrm{L})$ & $118.4(49.2-211.6)$ & $82.6(20.7-131.3)$ & $146.2(55.7-241.2)$ & $0.0058^{\#}$ & - \\
\hline Glomerular Filtration Rate $(\mathrm{mL} / \mathrm{min})$ & $81.5(39.5-101.5)$ & $86.5(67.8-99.3)$ & $79.5(37.3-102.8)$ & $0.41^{\#}$ & \\
\hline D-dimer $(\mathrm{ng} / \mathrm{mL})$ & $1110(594-2024)$ & $985(529-1392)$ & $1211(594-2221)$ & $0.37^{\#}$ & - \\
\hline Alanine aminotransferase (ALT) (IU/mL) & $33(22.0-53.8)$ & $30(18-51.3)$ & $33(23-64.3)$ & $0.2382^{\#}$ & \\
\hline Lactate dehydrogenase (LDH) (U/L) & $386(293-451.3)$ & $327(201.3-420.5)$ & $398(307.5-495.5)$ & $0.0192^{\#}$ & \\
\hline Troponin $(\mathrm{pg} / \mathrm{mL})$ & $12.9(8.8-29.6)$ & $12.3(6.0-17.3)$ & $13.1(9.85-39.6)$ & $0.0970^{\#}$ & \\
\hline
\end{tabular}

tQuantitative results were expressed as median (IQR)

"Pearson's Chi-squared test

\#Mann-Whitney 
medRxiv preprint doi: https://doi.org/10.1101/2021.09.28.21264239; this version posted October 1, 2021. The copyright holder for this preprint (which was not certified by peer review) is the author/funder, who has granted medRxiv a license to display the preprint in perpetuity.

All rights reserved. No reuse allowed without permission.

\section{Figure legends}

Figure 1. SARS-CoV-2 N-Ag in urine and plasma samples. A) Detection of urine N-Ag according to the week since the onset of symptoms in SARS-CoV-2-infected patients. Proportion of patients tested positive for $\mathrm{N}-\mathrm{Ag}$ in urine were represented in yellow. B) Detection of plasma $\mathrm{N}-\mathrm{Ag}$ according to the week since the onset of symptoms in SARS-CoV-2-infected patients. Proportion of patients tested positive for $\mathrm{N}-\mathrm{Ag}$ in plasma were represented in blue. $\mathrm{C}$ ) Urine $\mathrm{N}-\mathrm{Ag}$ levels according to the time since the onset of symptoms, with exponential fits (dotted line). D) Plasma N-Ag levels according to the time since the onset of symptoms. E) $\mathrm{N}$-Ag levels in matched urine and plasma samples. F) Longitudinal assessment of $\mathrm{N}-\mathrm{Ag}$ in urine samples collected in seven patients (dotted line: lower limit of detection). G) Longitudinal assessment of $\mathrm{N}-\mathrm{Ag}$ in urine samples collected in seven patients (dotted line: lower limit of detection). Matched urine and plasma samples have the same symbol and color. H) Urine $\mathrm{N}-\mathrm{Ag}$ according to serological status for $\mathrm{N}-\mathrm{Ig}$. I) Plasma N-Ag according to serological status for $\mathrm{N}-\operatorname{lgG}$. J) N-Ag in urine as a function of PCR cycle threshold (Ct) in nasopharyngeal samples, with exponential fits (solid lines). K) N-Ag in plasma as a function of PCR cycle threshold (Ct) in nasopharyngeal samples, with exponential fits (solid lines).

Figure 2. SARS-CoV-2 nucleocapsid-IgG ( $\mathrm{N}-\lg G)$ and $-\operatorname{lgA}(\mathrm{N}-\operatorname{lgA})$ in plasma and urine samples. $\mathrm{A})$ Nucleocapisd antibody levels in plasma, IgG (blue circles), IgA (blue square), limite of positivity (doted line). B) Nucleocapisd levels in urine according to plasma nucleocapsid status; urine N-IgG in plasma $\mathrm{N}$-IgG negative patients (white circles) and plasma N-IgA positive patients (red circles); urine $\mathrm{N}$-IgA in plasma $\mathrm{N}$-lgA negative patients (white triangles) and plasma $\mathrm{N}$-lgA positive patients (red triangles). Nucleocapsid antibody levels were expressed as a percentage sample/positive control ratio (S/P\%).

Figure 3. SARS-CoV-2 N-Ag according to Covid-19 severity in hospitalized patients. A) Urine $\mathrm{N}-\mathrm{Ag}$ levels in patients hospitalized in intensive care units (yellow circle) versus medical wards (yellow triangle) and according to serological status for N-IgG. B) Plasma N-Ag levels in patients hospitalized in intensive care units (blue circle) versus medical wards (blue triangle) and according to serological status for $\mathrm{N}-\lg$. C) Receiver operating characteristic curve (ROC) evaluating the ability of urine $\mathrm{N}-\mathrm{Ag}$ levels to discriminate patients hospitalized in intensive care units versus medical wards (Black: all patients; red: nucleocapside-lgG seronegative patients; blue: nucleocapsid-IgG seropositive patients). D) ROC evaluating the ability of plasma $\mathrm{N}-\mathrm{Ag}$ levels to discriminate patients hospitalized in intensive care units versus medical wards (Black: all patients; red: nucleocapside-lgG seronegative patients; blue: nucleocapsid-IgG seropositive patients). 
medRxiv preprint doi: https://doi.org/10.1101/2021.09.28.21264239; this version posted October 1, 2021. The copyright holder for this preprint

(which was not certified by peer review) is the author/funder, who has granted medRxiv a license to display the preprint in perpetuity.

All rights reserved. No reuse allowed without permission.

Figure 4. Association of $\mathrm{N}-\mathrm{Ag}$ levels with biological indicators of Covid-19 severity. A) N-Ag levels in urine according to $\mathrm{C}$-reactive protein (CRP) and $\mathrm{N}$-IgG serological status. $\mathrm{B}$ ) $\mathrm{N}$-Ag levels in plasma according to CRP and N-IgG serological status. C) N-Ag levels in urine according to lymphocyte count and $\mathrm{N}$-lgG serological status. D) N-Ag levels in plasma according to lymphocyte count and $\mathrm{N}$-lgG serological status. E) N-Ag levels in urine according to eosinophil count and N-IgG serological status. F) N-Ag levels in urine according to eosinophil count and N-IgG serological status. G) N-Ag levels in urine according to Glomerular Filtration Rate (GFR) and N-IgG serological status. $\mathrm{H}$ ) N-Ag levels in plasma according to GFR and N-IgG serological status. I) N-Ag levels in urine according to D-dimer level and $\mathrm{N}$-IgG serological status. J) $\mathrm{N}$-Ag levels in urine according to D-dimer level and $\mathrm{N}$-lgG serological status. K) N-Ag levels in urine according to lactate dehydrogenase (LDH) level and N-IgG serological status. L) N-Ag levels in plasma according to LDH levels and N-IgG serological status. M) NAg levels in urine according to alanine aminotransferase (ALT) level and N-IgG serological status. $N$ ) $\mathrm{N}-\mathrm{Ag}$ levels in plasma according LDH level and $\mathrm{N}-\mathrm{IgG}$ serological status. 
medRxiv preprint doi: https://doi.org/10.1101/2021.09.28.21264239; this version posted October 1, 2021. The copyright holder for this preprint Figure 1 ( $\mathbf{1}$ (A-K) was not certified by peer review) is the author/funder, who has granted medRxiv a license to display the preprint in perpetuity.

A

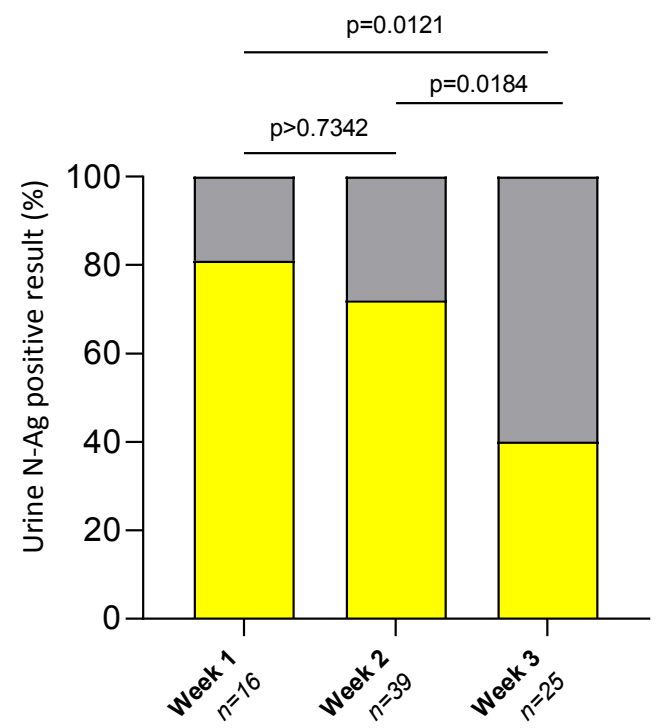

C

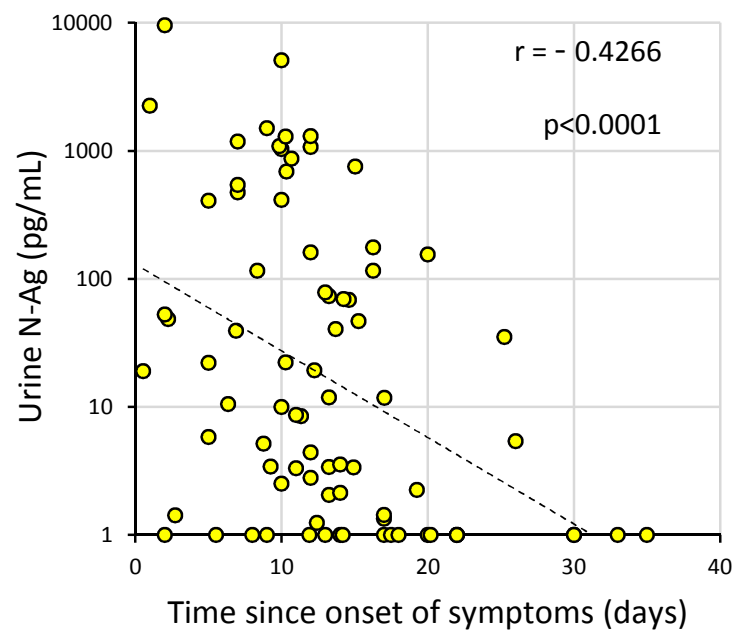

$\mathrm{E}$

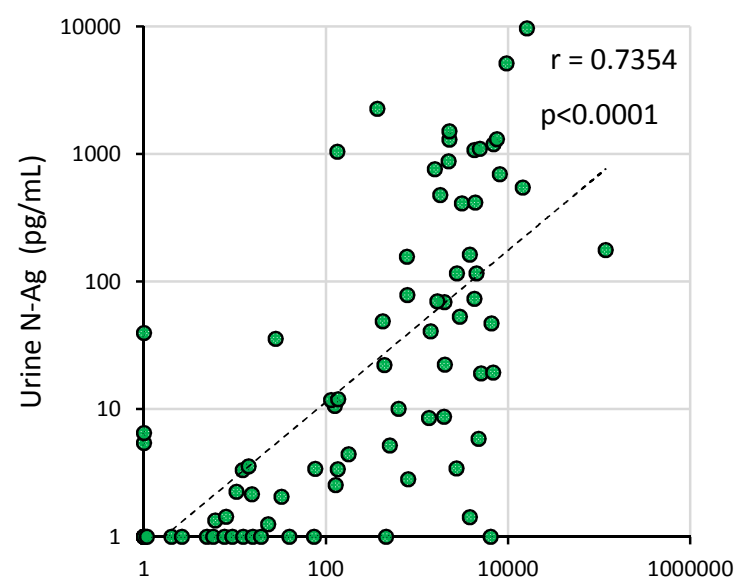

Plasma N-Ag $(\mathrm{pg} / \mathrm{mL})$
B

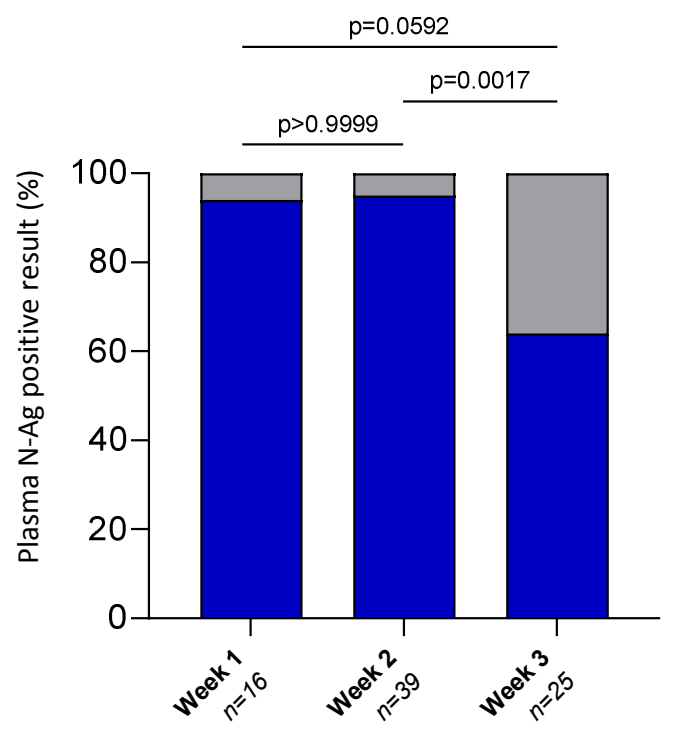

D

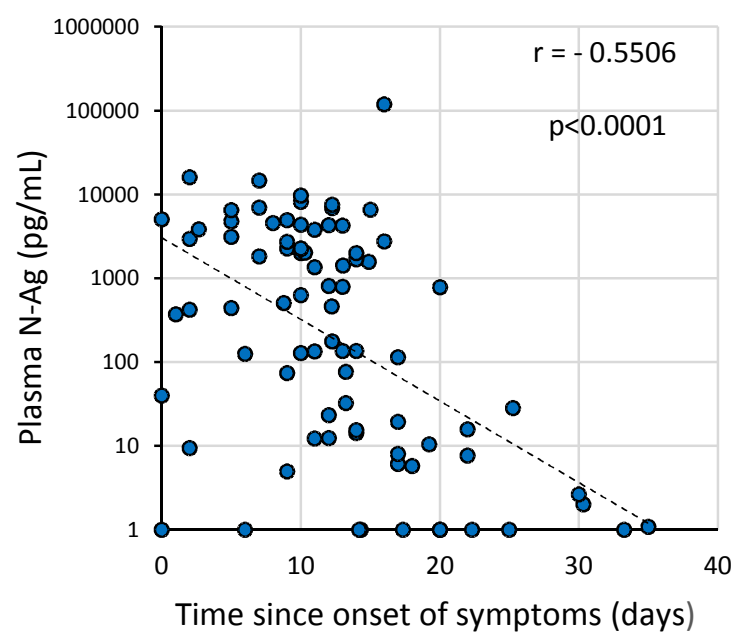


medRxiv preprint doi: https://doi.org/10.1101/2021.09.28.21264239; this version posted October 1, 2021. The copyright holder for this preprint (which was not certified by peer review) is the author/funder, who has granted medRxiv a license to display the preprint in perpetuity. All rights reserved. No reuse allowed without permission.

F

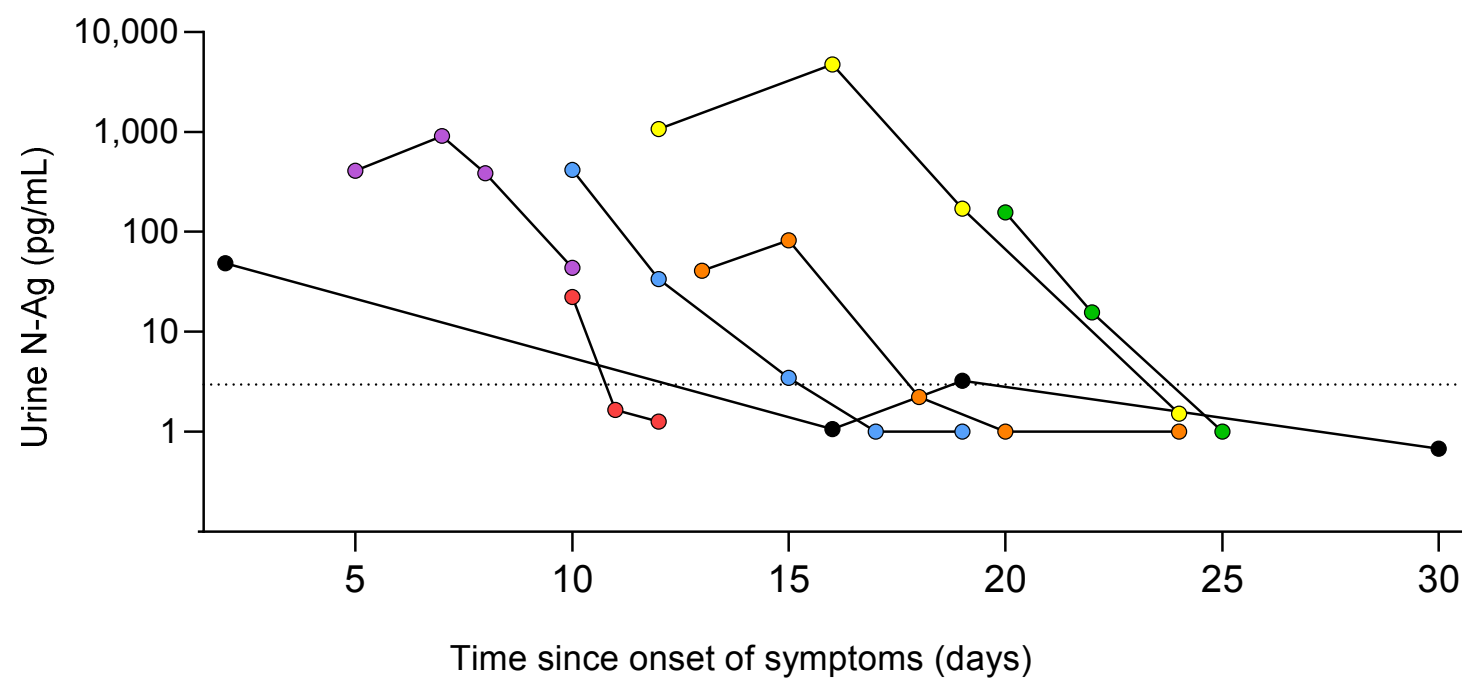

G

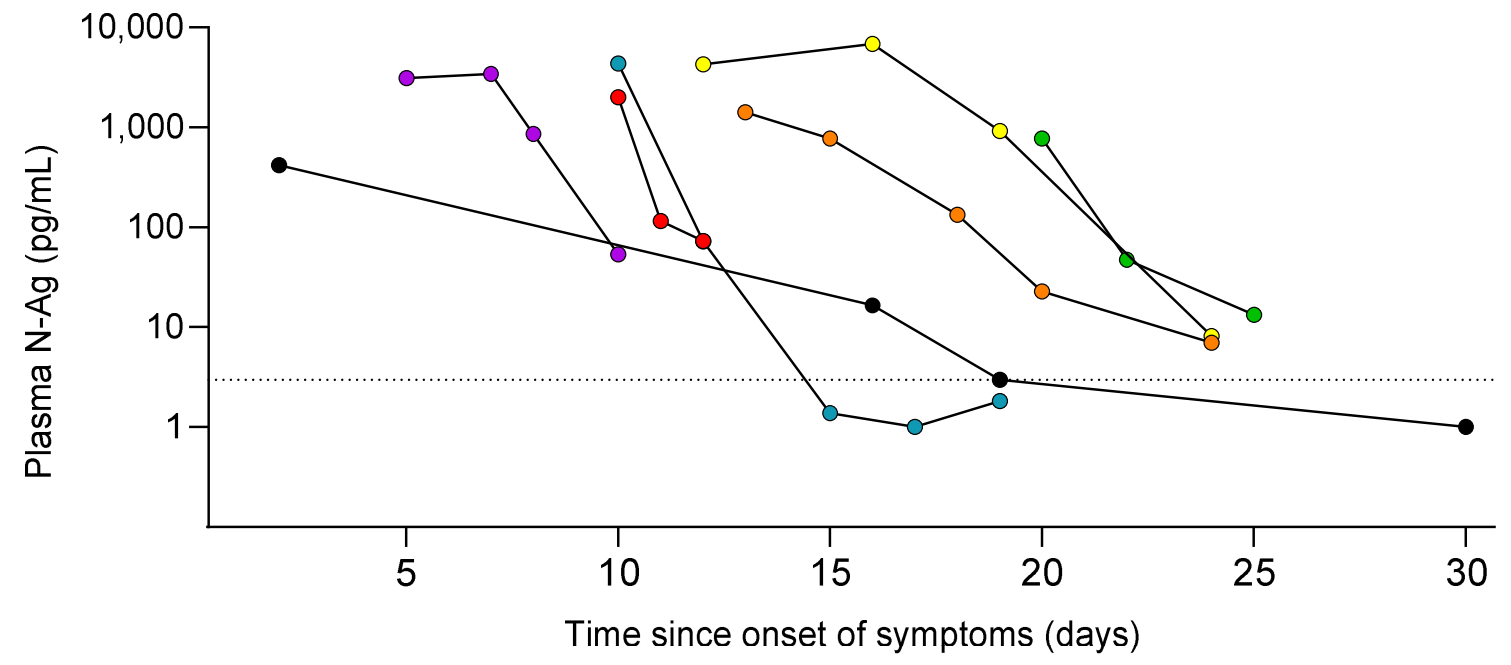


$\mathrm{H}$

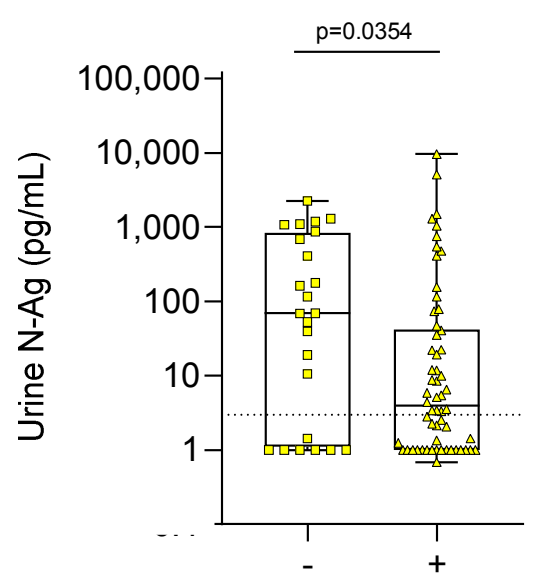

Plasma N-lgG
I

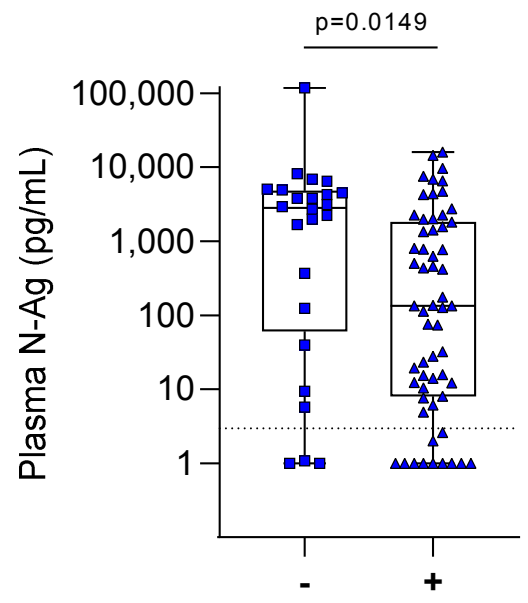

Plasma N-IgG
J

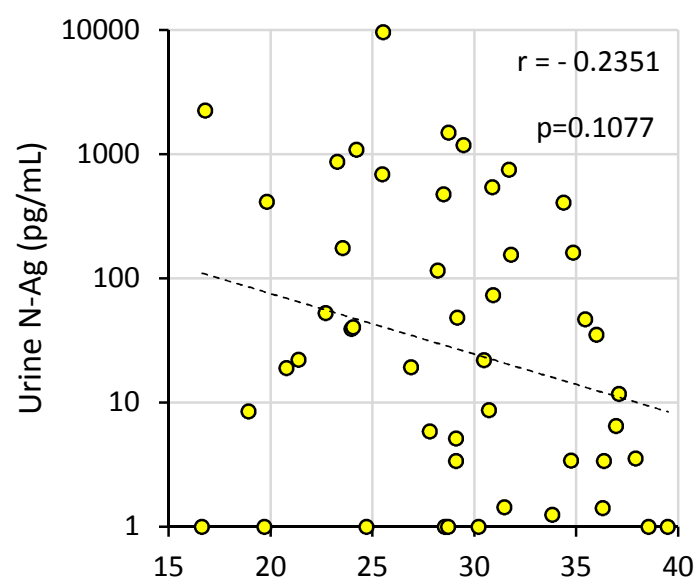

Nasopharyngeal SARS-CoV-2 PCR (CT)
K

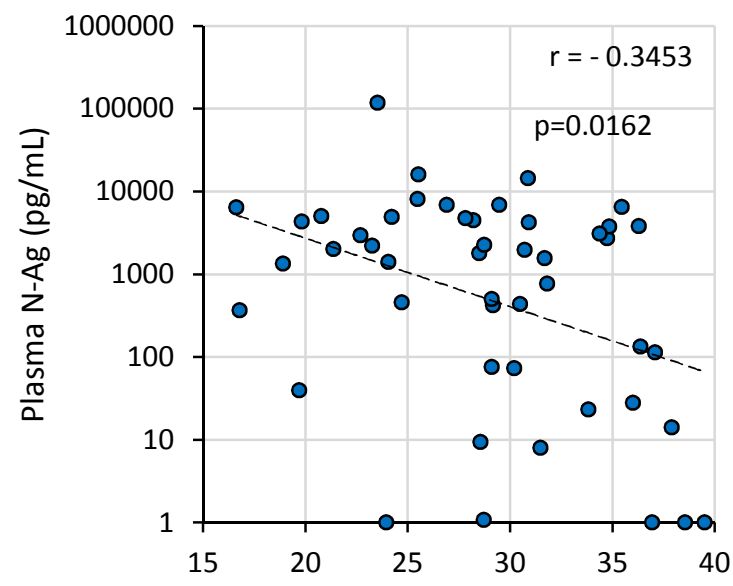

Nasopharyngeal SARS-CoV-2 PCR (CT)

Figure 1. SARS-CoV-2 N-Ag in urine and plasma samples. A) Detection of urine N-Ag according to the week since the onset of symptoms in SARS-CoV-2-infected patients. Proportion of patients tested positive for $\mathrm{N}$-Ag in urine were represented in yellow. B) Detection of plasma N-Ag according to the week since the onset of symptoms in SARS-CoV-2-infected patients. Proportion of patients tested positive for $\mathrm{N}$-Ag in plasma were represented in blue. $\mathrm{C}$ ) Urine $\mathrm{N}$-Ag levels according to the time since the onset of symptoms, with exponential fits (doted line). D) Plasma N-Ag levels according to the time since the onset of symptoms. E) N-Ag levels in matched urine and plasma samples. F) Longitudinal assessment of $\mathrm{N}-\mathrm{Ag}$ in urine samples collected in seven patients (doted line: lower limit of detection). G) Longitudinal assessment of $\mathrm{N}$-Ag in urine samples collected in seven patients (doted line: lower limit of detection). Matched urine and plasma samples have the same symbol and color. H) Urine N-Ag according to serological status for N-IgG. I) Plasma N-Ag according to serological status for N-IgG. J) N-Ag in urine as a function of PCR cycle threshold (Ct) in nasopharyngeal samples, with exponential fits (solid lines). K) N-Ag in plasma as a function of PCR cycle threshold (Ct) in nasopharyngeal samples, with exponential fits (solid lines). 
A

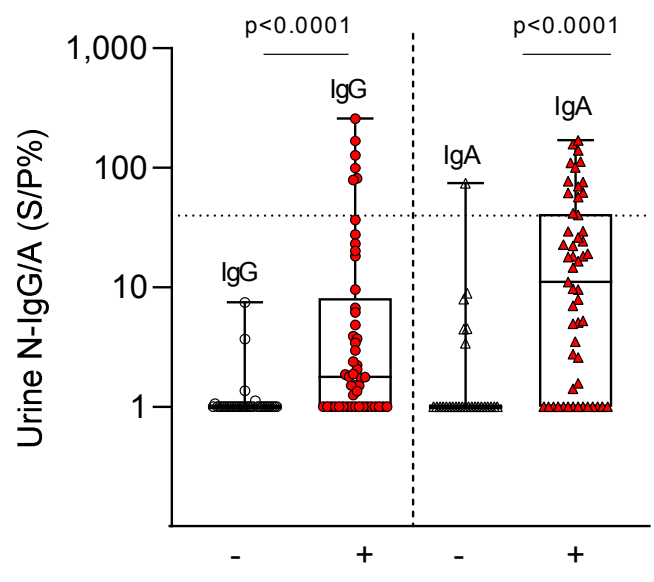

Plasma N-lgG Plasma N-lgA
B

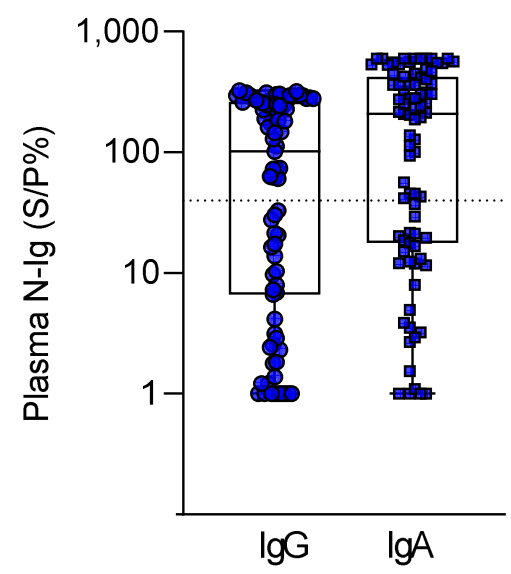

Figure 2. SARS-CoV-2 nucleocapsid-IgG (N-IgG) and -IgA (N-IgA) in plasma and urine samples. A) Nucleocapisd antibody levels in plasma, IgG (blue circles), IgA (blue square), limite of positivity (doted line). B) Nucleocapisd levels in urine according to plasma nucleocapsid status; urine N-IgG in plasma N-IgG negative patients (white circles) and plasma N-IgA positive patients (red circles); urine N-IgA in plasma N-IgA negative patients (white triangles) and plasma N-IgA positive patients (red triangles). Nucleocapsid antibody levels were expressed as a percentage sample/positive control ratio (S/P\%). 
A

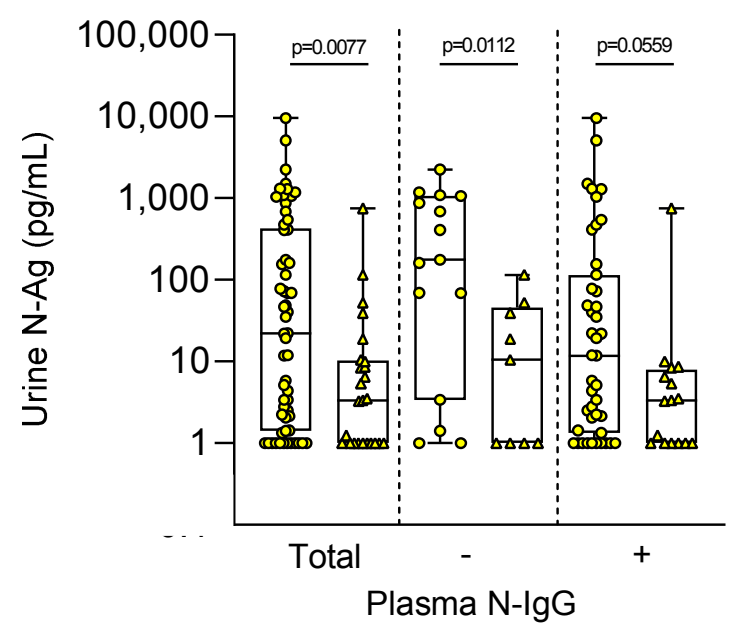

C

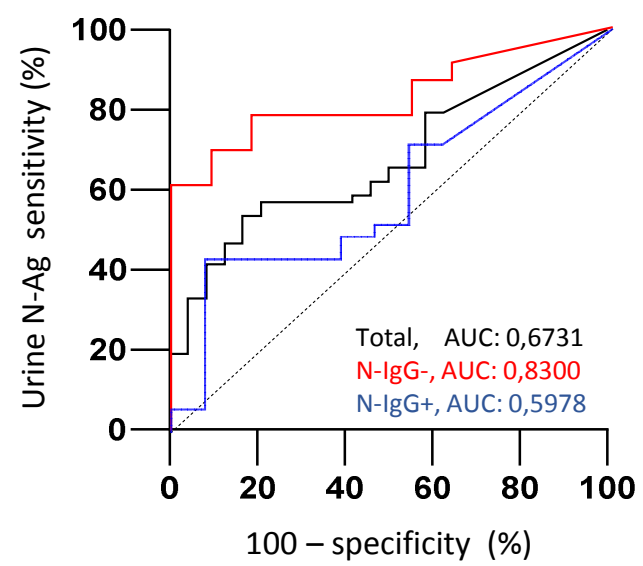

B

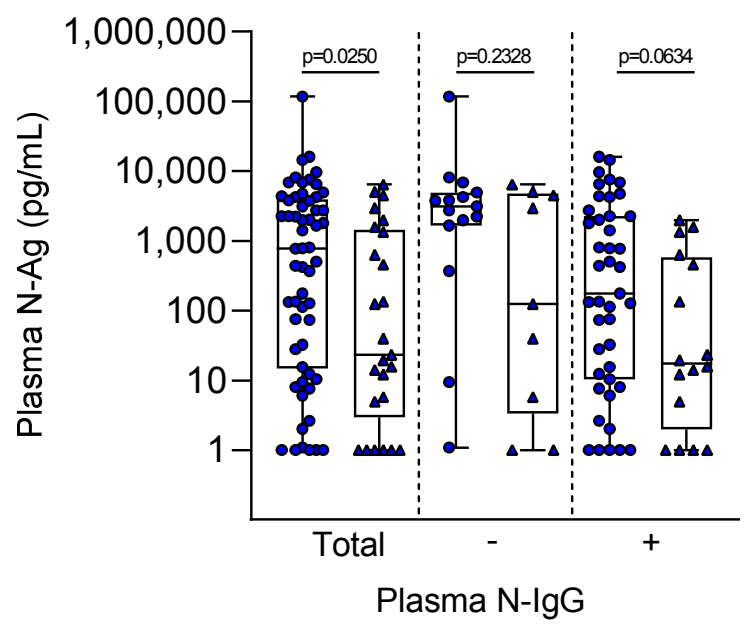

D

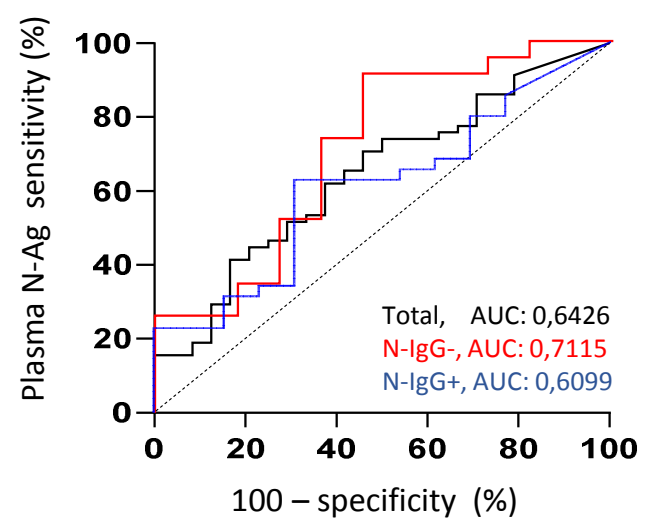

Figure 3. SARS-CoV-2 N-Ag according to Covid-19 severity in hospitalized patients. A) Urine N-Ag levels in patients hospitalized in intensive care units (yellow circle) versus medical wards (yellow triangle) and according to serological status for $\mathrm{N}-\operatorname{lgG}$. B) Plasma $\mathrm{N}-\mathrm{Ag}$ levels in patients hospitalized in intensive care units (blue circle) versus medical wards (blue triangle) and according to serological status for N-IgG. C) Receiver operating characteristic curve (ROC) evaluating the ability of urine $\mathrm{N}-\mathrm{Ag}$ levels to discriminate patients hospitalized in intensive care units versus medical wards (Black: all patients; red: nucleocapside-IgG seronegative patients; blue: nucleocapsid-IgG seropositive patients). D) ROC evaluating the ability of plasma $\mathrm{N}$-Ag levels to discriminate patients hospitalized in intensive care units versus medical wards (Black: all patients; red: nucleocapside-lgG seronegative patients; blue: nucleocapsid-IgG seropositive patients). 
medRxiv preprint doi: https://doi.org/10.1101/2021.09.28.21264239; this version posted October 1, 2021. The copyright holder for this preprint Figure $3^{\text {which }}(\mathbf{A}-\mathrm{D})$ nos not certified by peer review) is the author/funder, who has granted medRxiv a license to display the preprint in perpetuity.

A

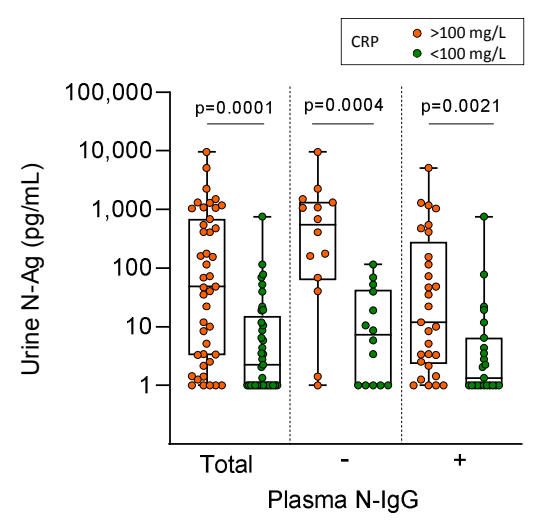

C

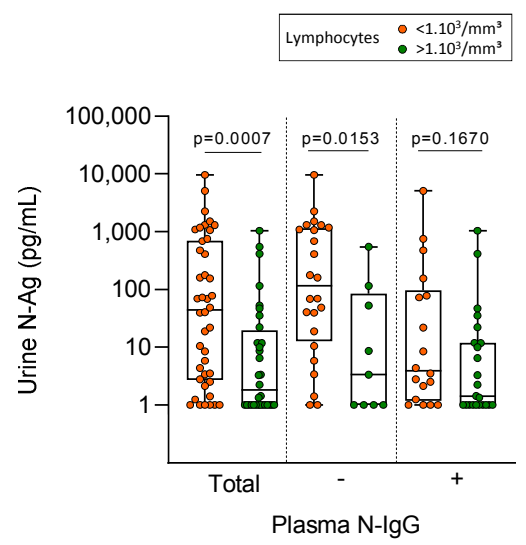

$\mathrm{E}$

Eosinophiles $\quad 0<0.1 .10^{3} / \mathrm{mm}^{3}$

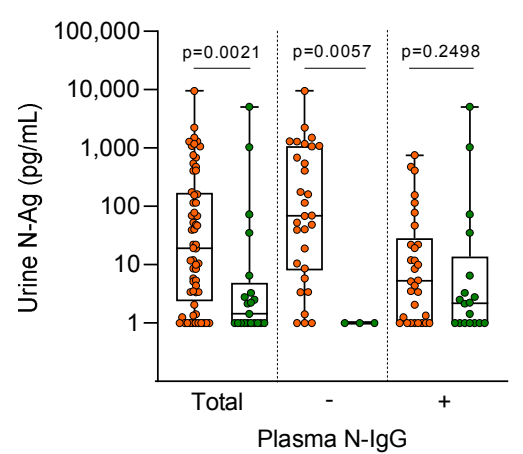

B

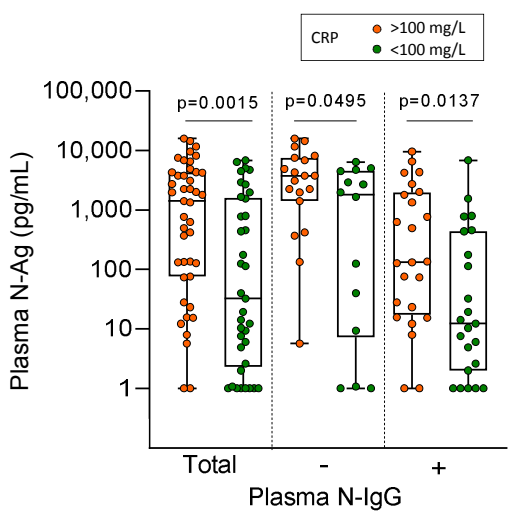

D

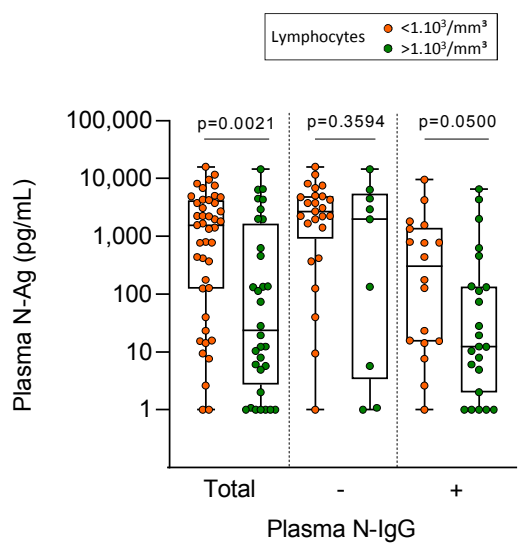

$\mathrm{F}$

Eosinophiles $:<0.1 .10^{3} / \mathrm{mm}^{3}$

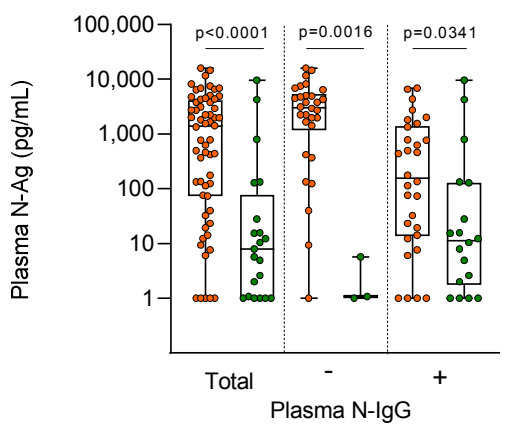


medRxiv preprint doi: https://doi.org/10.1101/2021.09.28.21264239; this version posted October 1, 2021. The copyright holder for this preprint (which was not certified by peer review) is the author/funder, who has granted medRxiv a license to display the preprint in perpetuity.

G

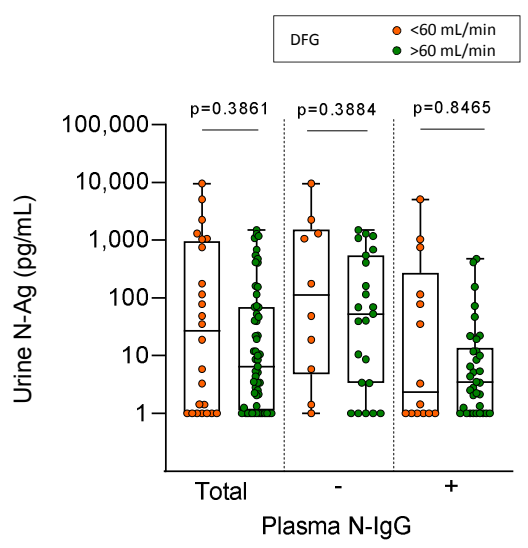

I

D-dimer $\quad:>1200 \mathrm{ng} / \mathrm{mL}$

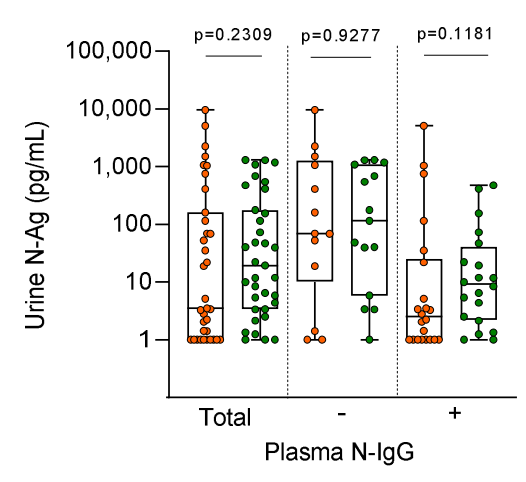

$\mathrm{K}$
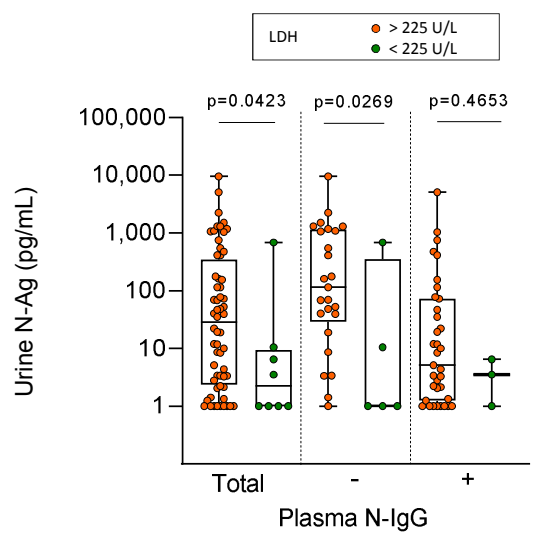

All rights reserved. No reuse allowed without permission.

L

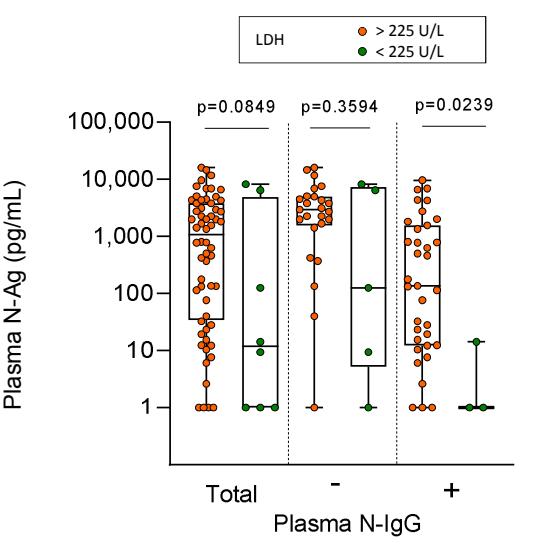


M

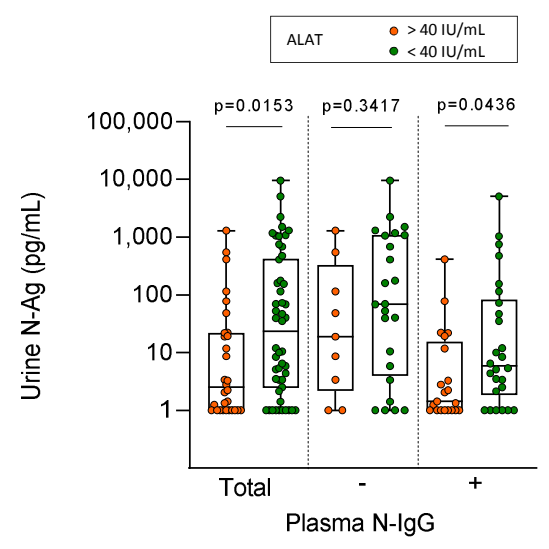

$\mathrm{O}$

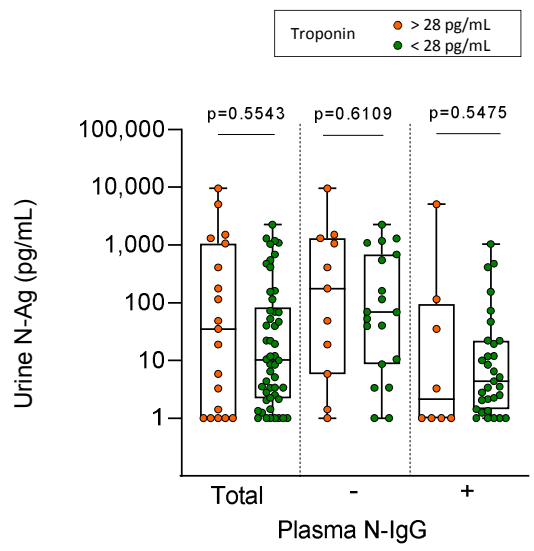

$\mathrm{N}$

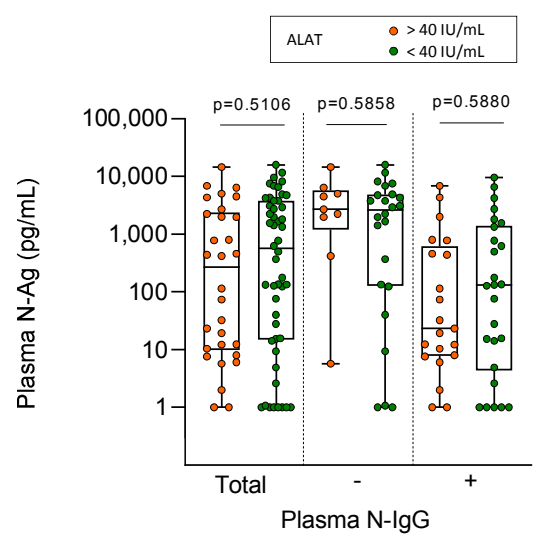

$\mathrm{P}$

Troponin $0>28 \mathrm{pg} / \mathrm{mL}$

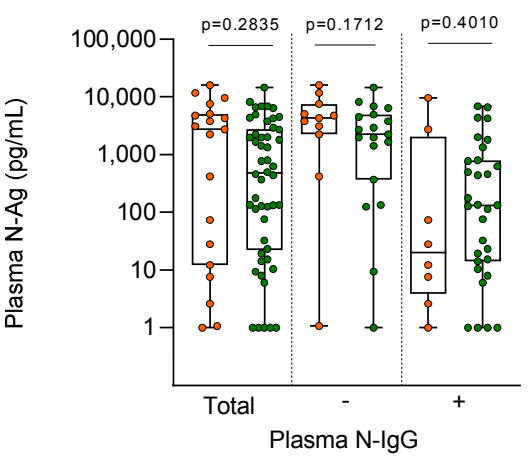

Figure 4. Association of $\mathrm{N}-\mathrm{Ag}$ levels with biological indicators of Covid-19 severity. A) N-Ag levels in urine according to $\mathrm{C}$-reactive protein (CRP) and $\mathrm{N}$-lgG serological status. B) N-Ag levels in plasma according to $\mathrm{CRP}$ and $\mathrm{N}$ IgG serological status. C) N-Ag levels in urine according to lymphocyte count and N-IgG serological status. D) N-Ag levels in plasma according to lymphocyte count and N-IgG serological status. E) N-Ag levels in urine according to eosinophil count and $\mathrm{N}-\lg \mathrm{G}$ serological status. F) N-Ag levels in urine according to eosinophil count and $\mathrm{N}$-lgG serological status. G) N-Ag levels in urine according to Glomerular Filtration Rate (GFR) and N-IgG serological status. $\mathrm{H}) \mathrm{N}$-Ag levels in plasma according to GFR and N-IgG serological status. I) N-Ag levels in urine according to D-dimer level and N-IgG serological status. J) N-Ag levels in urine according to D-dimer level and N-IgG serological status. K) $\mathrm{N}-\mathrm{Ag}$ levels in urine according to lactate dehydrogenase (LDH) level and N-IgG serological status. L) N-Ag levels in plasma according to LDH levels and N-IgG serological status. M) N-Ag levels in urine according to alanine aminotransferase (ALT) level and N-IgG serological status. $\mathrm{N}$ ) N-Ag levels in plasma according LDH level and N-IgG serological status. 